\title{
PENGEMBANGAN PAKET LATIHAN DAN PENILAIAN BERBANTUAN KOMPUTER UNTUK PEMBELAJARAN ALAT UKUR MEKANIK PRESISI
}

\author{
Surono $^{1}$, Chrisna Tri Hajanto ${ }^{2}$ \\ ${ }^{1,2}$ Jurusan Pendidikan Teknik Mesin, Universitas Negeri Yogyakarta \\ suronogk@uny.ac.id
}

\begin{abstract}
This study aims to: (1) formulate the steps to develop a computer-aided training and assessment packages for the learning materials of precision mechanical measuring devices, (2) obtain a computer-aided training and assessment packages that are applicable for use in learning process. The research type is Research and Development $(R \& D)$, which was referred to the Borg \& Gall model modified by Sukmadinata (2009), and the model developed by Sugiyono (2011). The research was conducted at SMK Negeri 2 Wonosari. The data collection were using questionnaire instruments and the computer-aided training and assessment packages. The research data were analyzed using descriptive statistical analysis techniques. The results of this study are as follows. (1) The steps in developing computer-aided training and assessment packages are preliminary studies, production, product evaluation, and dissemination; (2) The developed computer-aided training and assessment packages is suitable for use in learning process based on the expert validation and students' responses. The validation from the material learning experts resulted in a mean score of 4.46 (excellent category); validation from the assessment experts obtained a mean score of 4.41 (excellent category); and validation from the learning media experts obtained a mean score of 4.55 (excellent category). The mean score of students' responses in the beta test was 4.06 (good category), and the mean score in the summative evaluation was 4.00 (good category).
\end{abstract}

Keywords: development, training and assessment packages, computer-aided

\begin{abstract}
ABSTRAK
Penelitian ini bertujuan untuk: (1) merumuskan langkah-langkah pengembangan paket latihan dan penilaian berbantuan komputer untuk materi pembelajaran alat ukur mekanik presisi, (2) mendapatkan paket latihan dan penilaian berbantuan komputer yang layak digunakan dalam pembelajaran. Jenis penelitian ini adalah research and development $(R \& D)$, mengacu pada model Borg \& Gall yang telah dimodifikasi oleh Sukmadinata (2009) dan model yang dikembangkan Sugiyono (2011). Lokasi penelitian di SMK Negeri 2 Wonosari. Instrumen pengumpulan data yang digunakan adalah angket, serta paket latihan dan penilaian berbantuan komputer. Data penelitian dianalisis menggunakan teknik analisis statistik deskriptif. Hasil penelitian ini adalah sebagai berikut. (1) Langkah-langkah pengembangan paket latihan dan penilaian berbantuan komputer dilakukan melalui empat tahap, yaitu studi pendahuluan, produksi, evaluasi produk, dan diseminasi; (2) Paket latihan dan penilaian berbantuan komputer yang dikembangkan layak digunakan dalam pembelajaran berdasarkan validasi ahli dan tanggapan siswa. Validasi oleh ahli materi memperoleh rerata skor 4,46 dengan kategori sangat baik; validasi oleh ahli evaluasi memperoleh rerata skor 4,41 dengan kategori sangat baik; dan validasi oleh ahli media memperoleh rerata skor 4,55 dengan kategori sangat baik. Rerata skor tanggapan siswa pada beta test adalah 4,06 dengan kategori baik, dan rerata skor pada evaluasi sumatif adalah 4,00 dengan kategori baik.
\end{abstract}

Kata kunci: pengembangan, paket latihan dan penilaian, berbantuan computer

\section{PENDAHULUAN}

Kemampuan mengukur dengan alat ukur mekanik presisi merupakan kompetensi yang mutlak harus dikuasai oleh lulusan SMK bidang keahlian teknik mesin untuk dapat bekerja pada bidang yang sesuai. Kompetensi ini sangat mendukung dan bahkan mendasari pencapaian kompetensi lain, khususnya kompetensi dalam penggunaan mesin perkakas, perawatan, dan kontrol kualitas.
Sehingga, hampir mustahil lulusan SMK dapat bekerja dalam bidang teknik mesin tanpa menguasai kompetensi ini. Oleh karena itu penguasaan kompetensi pengukuran dengan alat ukur mekanik presisi merupakan kebutuhan yang harus terpenuhi. Namun demikian, dalam pelaksanaan di lapangan sering terdapat permasalahan yang menyulitkan siswa maupun guru. Permasalahan yang sering dijumpai antara lain 
tidak meratanya sarana, prasarana, dan fasilitas yang mendukung pembelajaran.

Berdasarkan hasil observasi diketahui bahwa ruangan dan peralatan yang dimiliki oleh sekolah belum memadai untuk melakukan kegiatan praktik pengukuran teknik yang ideal. Laboratorium pengukuran teknik berdekatan dengan bengkel yang memiliki tingkat kebisingan tinggi, ruangan panas, dan berdebu. Selain itu, siswa tidak mendapatkan latihan yang cukup mengingat jumlah alat dan waktu praktik yang terbatas.

Berdasarkan hasil wawancara, diketahui bahwa guru belum pernah membuat media pembelajaran sendiri, apalagi yang berbentuk multimedia. Pembelajaran dominan menggunakan white board dan alat lebar gantung (ALG/wallchart) sehingga tidak dapat menampilkan simulasi/animasi. Pembelajaran pun cenderung menggunakan pendekatan konvensional yang menekankan pada teacher centered learning. Menurut guru, ketuntasan siswa juga masih rendah karena dua tahun terakhir baru mencapai antara $50-70 \%$. Selain itu, guru menilai bahwa keaktifan siswa dalam pembelajaran juga masih rendah. Siswa enggan bertanya ketika menemui kesulitan dalam memahami materi.

Hasil wawancara dengan siswa menunjukkan bahwa mereka sering merasa jenuh/bosan dalam pembelajaran. Mereka hanya mendengarkan penjelasan dan menyalin tulisan guru di white board. Keadaan tersebut membuat beberapa siswa kadang tertidur saat pelajaran berlangsung. Para siswa juga mengaku masih kesulitan memahami materi dengan metode pembelajaran yang dilakukan selama ini. Selain itu, karena alat praktik yang terbatas siswa harus mengantre. Ketika siswa ingin belajar di rumah, mereka juga kesulitan karena paket materi yang tersedia masih terbatas jumlahnya maupun isinya. Dengan keadaan demikian, dapat dipahami mengapa banyak siswa menemui kendala dalam pembelajaran alat ukur mekanik presisi. Permasalahan lain yang dialami adalah terkait dengan penilaian. Pelaksanaan penilaian mata diklat pengukuran hanya dilakukan di akhir pembelajaran ketika semua materi telah selesai, tidak pernah dilakukan ketika pembelajaran berlangsung.

Berdasarkan wawancara dan observasi di atas, maka perlu dicari jalan keluar untuk mengatasi segala permasalahan dan kendala yang dihadapi siswa dan guru. Kegiatan pertama adalah mencermati semua potensi yang dapat dimanfaatkan untuk mengatasi permasalahan. Hasilnya diketahui bahwa sekolah memiliki laboratorium komputer yang cukup memadai namun belum dimanfaatkan secara optimal. Laboratorium komputer yang ada di sekolah hanya digunakan untuk pembelajaran Computer Aided Design (CAD) saja. Selain komputer, fasilitas lain yang tersedia adalah perangkat Liquid Crystal Display (LCD) projector dan hotspot area. Berdasarkan wawancara, diperoleh informasi bahwa guru maupun siswa mempunyai kemampuan yang cukup untuk mengoperasikan komputer. Berdasarkan temuan tersebut dapat disimpulkan bahwa sekolah, guru, dan siswa memiliki potensi untuk memanfaatkan komputer sebagai multimedia pembelajaran.

Pemanfaatan komputer sebagai multimedia pembelajaran diharapkan dapat menjadi solusi terkait masalah waktu dan alat praktik yang terbatas. Multimedia pembelajaran memungkinkan kegiatan belajar dapat dilakukan kapanpun dan dimanapun dengan bantuan komputer. Selain itu, pemanfaatan multimedia pembelajaran diharapkan dapat mengatasi permasalahan suasana belajar yang cenderung monoton dan membosankan menurut siswa selama ini.

Permasalahan dalam penelitian ini dibatasi pada upaya mengembangkan dan menguji kelayakan paket latihan dan penilaian berbantuan komputer untuk pembelajaran alat ukur mekanik presisi. Sasaran calon penggunanya adalah siswa program keahlian Teknik Pemesinan kelas X. Materi yang dipilih yaitu: (1) identifikasi alat ukur mekanik presisi, (2) vernier caliper, dan (3) outside micrometer. Paket latihan dan penilaian ini merupakan sebuah aplikasi yang dijalankan pada perangkat komputer seperti personal computer ( $p c)$, notebook atau laptop, atau perangkat sejenisnya.

\section{METODE}

Jenis penelitian ini adalah research and development $(R \& D)$, mengacu pada model Borg \& Gall yang telah dimodifikasi oleh Sukmadinata (2009) dan model yang dikembangkan Sugiyono (2011). Lokasi penelitian di SMK Negeri 2 Wonosari, dengan 
responden siswa program keahlian Teknik Pemesinan kelas X. Instrumen pengumpulan data yang digunakan adalah angket, serta paket latihan dan penilaian berbantuan komputer. Data penelitian dianalisis menggunakan teknik analisis statistik deskriptif. Data dikategorikan menjadi lima kategori berdasarkan perhitungan dari kurva normal dan interpretasi datanya mengacu Tabel 1.

Tabel 1. Kriteria Interpretasi Data

\begin{tabular}{|c|c|c|c|}
\hline \multicolumn{3}{|c|}{ Interval Skor } & Kriteria \\
\hline 4,21 & $<X$ & & Sangat baik \\
\hline 3,40 & $<X \leq$ & 4,21 & Baik \\
\hline 2,60 & $<X \leq$ & 3,40 & Cukup baik \\
\hline 1,79 & $<X \leq$ & 2,60 & Kurang baik \\
\hline & $X \leq$ & 1,79 & Tidak baik \\
\hline
\end{tabular}

\section{HASIL DAN PEMBAHASAN}

Pengembangan paket latihan dan
penilaian berbantuan komputer untuk
pembelajaran alat ukur mekanik presisi
dilakukan melalui 4 (empat) langkah utama
yaitu: studi pendahuluan, produksi, evaluasi
produk, dan diseminasi. Pada tahap studi
pendahuluan, langkah yang dilakukan adalah
melakukan studi pustaka, survei lapangan, dan
merencanakan desain produk. Tahap-tahap
yang digunakan ini memiliki kesamaan dengan
penelitian Suartama (2010), Yazid (2009),
Wagiran (2008), dan Sutikanti (2008). Suartama membagi proses pengembangan multimedia menjadi lima tahap utama yaitu: (1) analisis kebutuhan, (2) desain pembelajaran, (3) produksi media, (4) evaluasi formatif, dan (5) evaluasi sumatif. Langkahlangkah teknis dalam pengembangan paket latihan dan penilaian yang dikembangkan banyak mengambil dan menyesuaikan dengan penelitian dari Yazid dan Sutikanti yang telah terbukti berhasil membuat produk yang layak dipakai dalam pembelajaran. Wagiran (2008) menyampaikan langkah pembuatan media yang dimulai dari identifikasi kompetensi, penulisan naskah, pemrograman dasar, pembuatan grafis, pembuatan animasi, pembuatan audio, pemrograman lengkap, tinjauan ahli, perbaikan tahap I, uji coba/uji empirik terbatas terhadap mahasiswa, perbaikan tahap dua, dan produk akhir. Perbedaan yang ada dari penelitian-penilitan tersebut bukan dari sisi substansi proses, tetapi lebih ke penyederhanaan dan jenis multimedia yang dikembangkan.

Hasil dari studi pendahuluan, diperoleh informasi bahwa: (1) metode yang digunakan dalam pembelajaran dominan menggunakan pendekatan konvensional yang menekankan pada teacher centered learning, sehingga siswa cenderung pasif, (2) laboratorium pengukuran kurang ideal karena bising, panas, dan berdebu, (3) peralatan praktik terbatas, (4) media yang digunakan adalah white board dan alat lebar gantung (ALG/wallchart) sehingga tidak ada simulasi/animasi pada media konvensional yang digunakan tersebut, (5) pembelajaran belum memanfaatkan media berbantuan komputer (multimedia) sehingga cenderung monoton dan siswa menjadi jenuh, (6) penilaian hanya dilakukan diakhir pembelajaran saja, (7) guru tidak membuat media pembelajaran sendiri karena belum pernah mendapat pelatihan membuat media pembelajaran. Hasil observasi berkaitan dengan fasilitas komputer yang dimiliki sekolah menunjukkan bahwa laboratorium komputer yang ada cukup memadai namun belum dimanfaatkan secara optimal. Selain komputer, fasilitas lain yang tersedia adalah perangkat Liquid Crystal Display (LCD) projector dan hotspot area yang juga belum maksimal penggunaannya. Guru tidak pernah memanfaatkan multimedia dalam pembelajaran, padahal sekolah memiliki potensi yang sangat besar untuk menunjang pembelajaran dengan multimedia. Hasil tanya jawab diperoleh keterangan bahwa guru maupun siswa mempunyai kemampuan yang cukup untuk mengoperasikan komputer.

Proses produksi paket latihan dan penilaian berbantuan komputer ini terdiri dari 5 (lima) tahapan yaitu: (1) pembuatan flowchart view (Gambar 1), (2) pembuatan storyboard, (3) pengumpulan bahan, (4) penyusunan (assembly), dan (5) tes secara modular hingga diperoleh produk awal. Flowchart view berfungsi sebagai diagram alir yang memberikan gambaran alir dari satu scene (tampilan) ke scene lainnya. Storyboard menggambarkan bentuk tampilan setiap scene yang berisi materi dan soal-soal sebagai paket latihan dan penilaian disertai dengan animasi, ilustrasi, gambar, grafik, audio, dan video. Berdasarkan flowchart view dan storyboard, maka bahan-bahan yang telah dikumpulkan sebelumnya disusun dan dimasukkan ke dalam 
paket latihan dan penilaian berbantuan komputer.

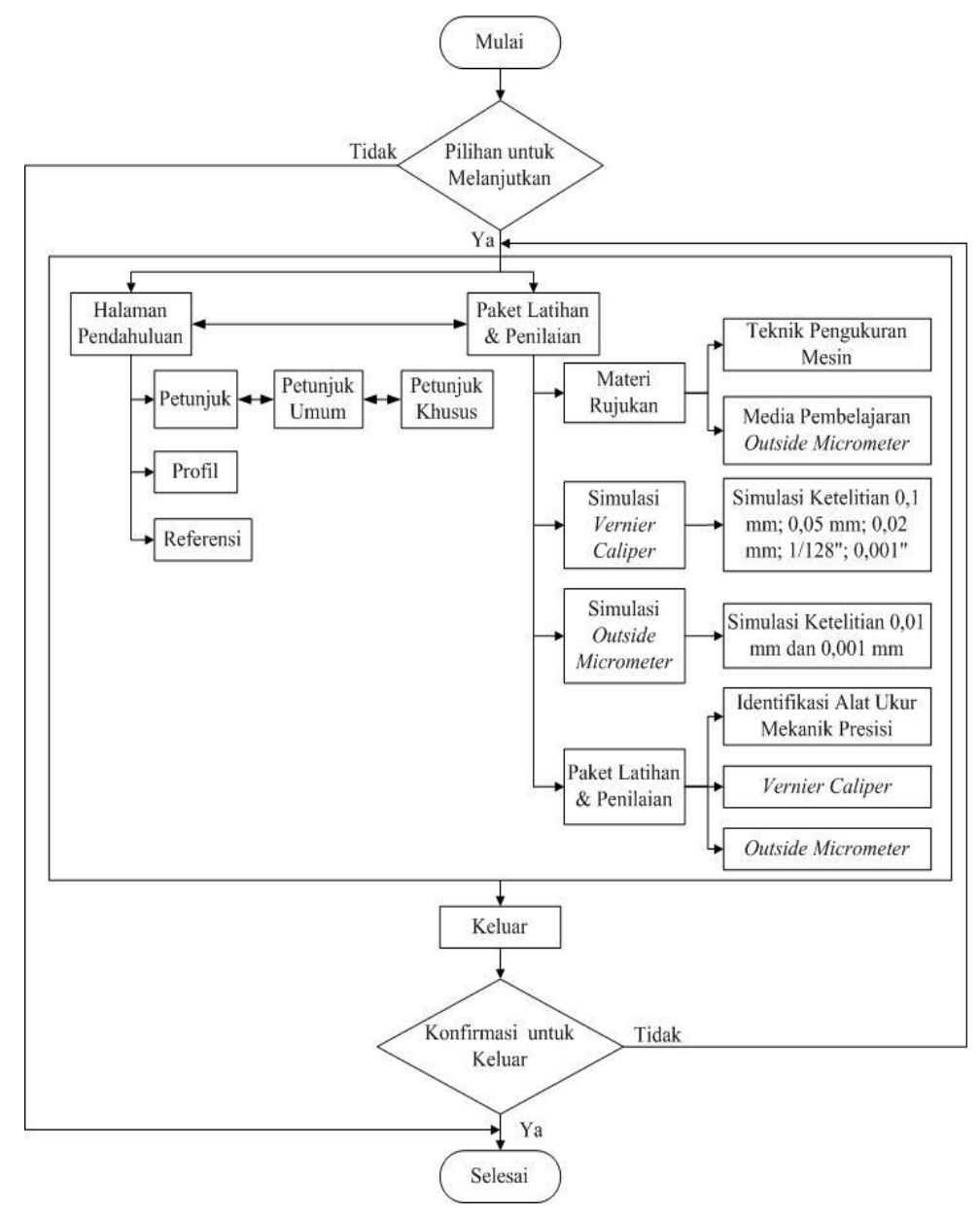

Gambar 1. Flowchart view

Tes secara modular dilakukan untuk mengetahui jalannya program menggunakan beberapa perangkat komputer yang berbedabeda namun memenuhi spesifikasi minimal yang dibutuhkan. Dengan cara ini diketahui 4 (empat) kesalahan/error yaitu: (1) beberapa tombol navigasi belum berfungsi dengan baik; (2) beberapa animasi dan aplikasi yang disisipkan dalam media belum berjalan semestinya; (3) audio belum berjalan dengan baik; dan (4) ukuran file yang terlalu besar sering menyebabkan error dan berjalan lambat. Perbaikan yang dilakukan adalah dengan cara: (1) memperbaiki fungsi navigasi agar berjalan sebagaimana mestinya; (2) animasi dan aplikasi yang belum berjalan baik disesuaikan dan ada yang diganti dengan animasi dan aplikasi lain yang sejenis; (3) melakukan instalasi software tambahan untuk dapat menjalankan aplikasi/animasi; dan (4) meng-convert audio dalam bentuk *.wav sehingga dapat disisipkan dalam presentasi. Setelah tes secara modular dan perbaikan pada beberapa kesalahan, produk awal dikemas dalam bentuk compact disk $(C D)$ untuk proses evaluasi. 

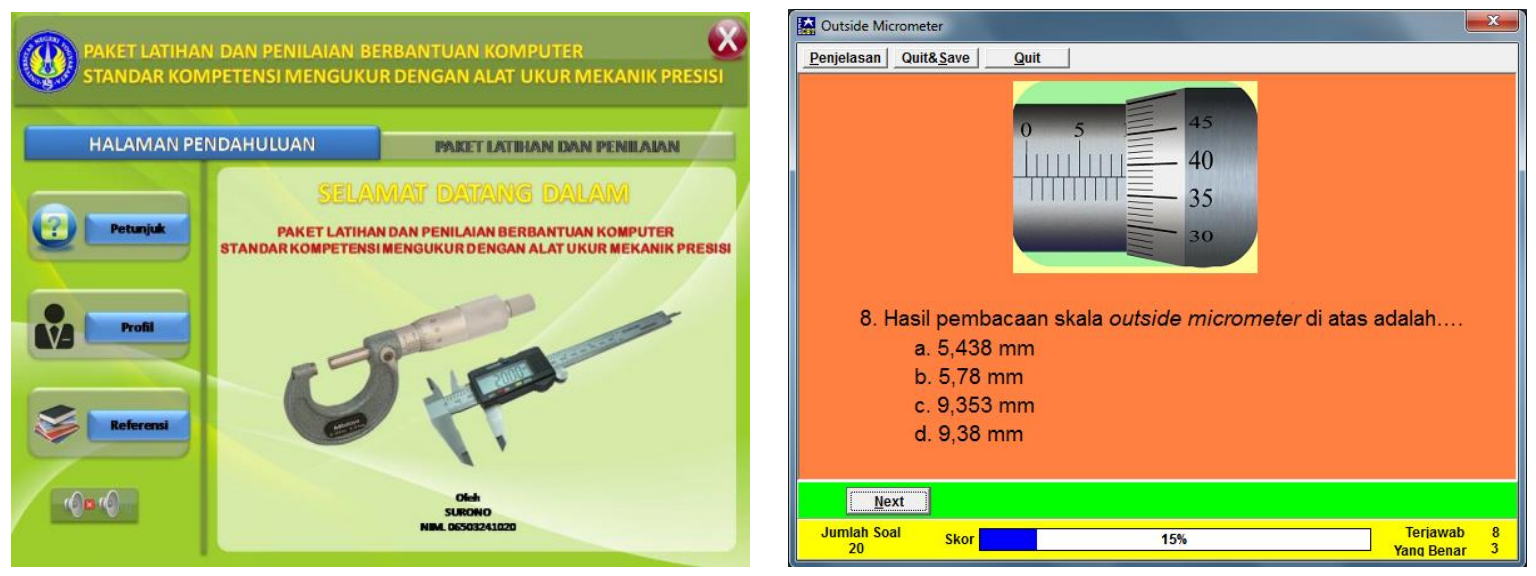

Gambar 2. Tampilan paket latihan dan penilaian berbantuan komputer untuk pembelajaran alat ukur mekanik presisi

Evaluasi produk dilakukan melalui alpha test/uji kelayakan oleh ahli (expert judgement) dan beta test (uji coba terbatas terhadap siswa). Penilaian kelayakan produk dilakukan oleh ahli materi, ahli evaluasi, dan ahli media yang masing-masing terdiri atas 3 (tiga) orang validator yang terdiri atas 7 orang dosen, 1 orang guru SMK, dan 1 orang praktisi multimedia. Beta test melibatkan 6 siswa kelas
$\mathrm{X}$ MC. Pemilihan siswa didasarkan pada tingkat kemampuan siswa yaitu 2 siswa berkemampuan tinggi, 2 siswa berkemampuan sedang, dan 2 siswa lainnya berkemampuan rendah.

Hasil validasi dari tiga ahli materi terhadap aspek kualitas materi dapat dilihat dalam Tabel 2.

Tabel 2. Skor penilaian oleh ahli materi

\begin{tabular}{|c|c|c|c|c|}
\hline No. & Kriteria Penilaian & \multicolumn{3}{|c|}{ Skor Penilaian } \\
\hline \multicolumn{5}{|c|}{ Kualitas Materi } \\
\hline 1. & $\begin{array}{l}\text { Kesesuaian penjabaran materi evaluasi dari standar kompetensi dan } \\
\text { kompetensi dasar }\end{array}$ & 5 & 4 & 4 \\
\hline 2. & Kesesuaian penjabaran materi evaluasi dari indikator & 5 & 4 & 4 \\
\hline 3. & Faktualisasi isi materi evaluasi & 5 & 4 & 4 \\
\hline 4. & Ketercakupan materi evaluasi berdasarkan materi yang diajarkan & 5 & 5 & 4 \\
\hline 5. & Kejelasan batasan ruang lingkup materi evaluasi & 5 & 5 & 3 \\
\hline 6. & Struktur organisasi/urutan materi evaluasi & 5 & 5 & 4 \\
\hline \multicolumn{2}{|r|}{ Rerata } & \multicolumn{3}{|c|}{4,44} \\
\hline \multicolumn{5}{|c|}{ Kemanfaatan Materi } \\
\hline 7. & Keberfungsian materi evaluasi dalam mengukur hasil belajar siswa & 5 & 5 & 4 \\
\hline 8. & Kesesuaian materi evaluasi dalam mengukur hasil belajar siswa & 5 & 5 & 3 \\
\hline 9. & Kesesuaian isi materi yang diujikan dengan jenjang sekolah/tingkat kelas & 5 & 5 & 4 \\
\hline 10. & Kesesuaian isi materi yang diujikan dengan kemampuan siswa & 5 & 4 & 4 \\
\hline 11. & Hubungan materi evaluasi dengan program pembelajaran lainnya & 5 & 4 & 4 \\
\hline & Rerata & \multicolumn{3}{|c|}{4,47} \\
\hline
\end{tabular}

Berdasarkan Tabel 2 rerata skor penilaian ahli materi dari aspek kualitas materi adalah 4,44 dan aspek kemanfaatan materi adalah 4,47. Kedua aspek tersebut termasuk dalam kategori "sangat baik". selain memberikan penilaian, ahli materi juga memberikan saran untuk memperbaiki gambar yang kurang jelas. Penilaian selanjutnya dilakukan oleh ahli evaluasi yang hasil selengkapnya disampaikan dalam Tabel 3. 
Tabel 3. Skor penilaian soal latihan oleh ahli evaluasi

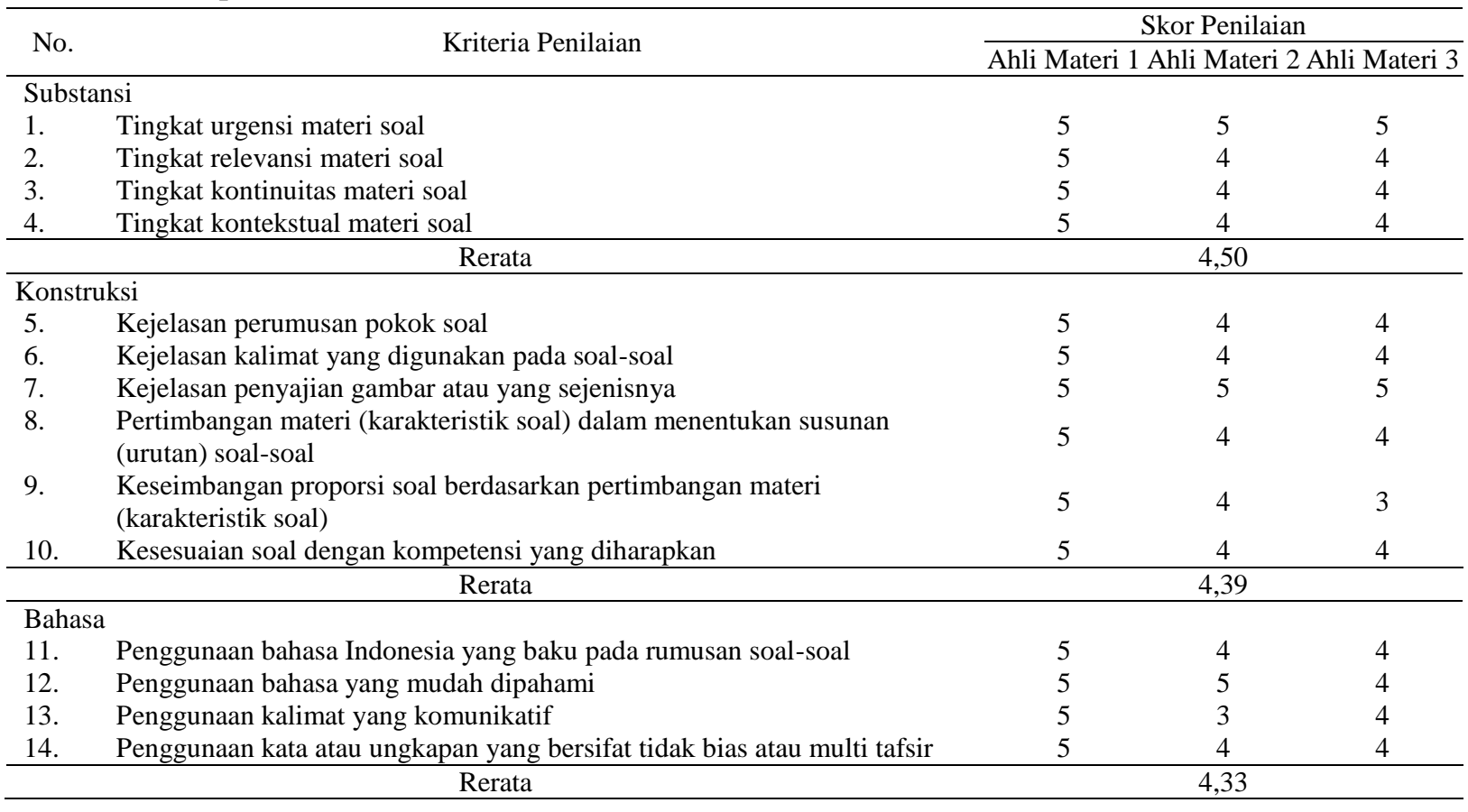

Berdasarkan Tabel 3 diketahui rerata skor penilaian pada aspek substansi soal adalah 4,50; aspek konstruksi 4,39; dan aspek bahasa 4,33. Berdasarkan rerata tersebut maka aspek substansi, konstruksi, dan bahasa dalam soal latihan termasuk kategori "sangat baik". Saran dari ahli evaluasi adalah perbaikan redaksi pada 21 soal latihan. Penilaian selanjutnya dilakukan oleh ahli media, yang selengkapnya disampaikan dalam Tabel 4.

Tabel 4. Skor penilaian oleh ahli media

\begin{tabular}{|c|c|c|c|c|}
\hline No. & Kriteria Penilaian & \multicolumn{3}{|c|}{ Skor Penilaian } \\
\hline \multicolumn{5}{|c|}{ Kualitas Tampilan } \\
\hline 1. & Kesesuaian pemilihan latar (background) & 5 & 5 & 4 \\
\hline 2. & Keterbacaan teks atau kalimat & 5 & 4 & 5 \\
\hline 3. & Ketepatan pemilihan ukuran huruf & 4 & 4 & 4 \\
\hline 4. & Ketepatan pemilihan bentuk/jenis huruf & 4 & 5 & 4 \\
\hline 5. & Ketepatan pemilihan warna huruf & 5 & 5 & 5 \\
\hline 6. & Komposisi warna tulisan terhadap warna latar (background) & 4 & 5 & 5 \\
\hline 7. & Kualitas sajian gambar/animasi & 5 & 5 & 5 \\
\hline 8. & Komposisi warna gambar animasi dengan latar (background) & 3 & 5 & 5 \\
\hline 9. & Keserasian tata letak & 4 & 5 & 4 \\
\hline \multicolumn{2}{|r|}{ Rerata } & \multicolumn{3}{|c|}{4,56} \\
\hline \multicolumn{5}{|c|}{ Konstruksi } \\
\hline 10. & Kejelasan perumusan pokok soal & 5 & 4 & 4 \\
\hline 11. & Kejelasan kalimat yang digunakan pada soal-soal & 5 & 4 & 4 \\
\hline 12. & Kejelasan penyajian gambar atau yang sejenisnya & 5 & 5 & 5 \\
\hline 13. & $\begin{array}{l}\text { Pertimbangan materi (karakteristik soal) dalam menentukan susunan } \\
\text { (urutan) soal-soal }\end{array}$ & 5 & 4 & 4 \\
\hline 14. & $\begin{array}{l}\text { Keseimbangan proporsi soal berdasarkan pertimbangan materi } \\
\text { (karakteristik soal) }\end{array}$ & 5 & 4 & 3 \\
\hline 15. & Kesesuaian soal dengan kompetensi yang diharapkan & 5 & 4 & 4 \\
\hline \multicolumn{2}{|r|}{ Rerata } & \multicolumn{3}{|c|}{4,39} \\
\hline \multicolumn{5}{|c|}{ Bahasa } \\
\hline 16. & Penggunaan bahasa Indonesia yang baku pada rumusan soal-soal & 5 & 4 & 4 \\
\hline 17. & Penggunaan bahasa yang mudah dipahami & 5 & 5 & 4 \\
\hline 18. & Penggunaan kalimat yang komunikatif & 5 & 3 & 4 \\
\hline 19. & Penggunaan kata atau ungkapan yang bersifat tidak bias atau multi tafsir & 5 & 4 & 4 \\
\hline & Rerata & \multicolumn{3}{|c|}{4,33} \\
\hline
\end{tabular}


Hasil beta test (uji coba terbatas dalam Tabel 5. terhadap siswa) selengkapnya disampaikan

Tabel 5. Skor tanggapan Siswa dalam Beta Test

\begin{tabular}{|c|c|c|c|c|c|c|c|}
\hline \multirow{2}{*}{ No. } & \multirow{2}{*}{ Kriteria Penilaian } & \multicolumn{6}{|c|}{ Skor Penilaian } \\
\hline & & 1 & 2 & 3 & 4 & 5 & 6 \\
\hline \multicolumn{8}{|c|}{ Kualitas Tampilan } \\
\hline 1. & Tampilan program/media menarik & 4 & 4 & 5 & 4 & 4 & 4 \\
\hline 2. & Teks/tulisan dalam program/media ini mudah dibaca & 4 & 4 & 4 & 4 & 3 & 3 \\
\hline 3. & Musik/suara yang digunakan dapat mendukung suasana belajar & 4 & 2 & 3 & 3 & 3 & 4 \\
\hline 4. & Gambar/animasi yang digunakan dalam program/media ini menarik & 3 & 5 & 3 & 5 & 5 & 4 \\
\hline 5. & $\begin{array}{l}\text { Gambar/animasi yang digunakan dalam program/media ini memudahkan saya memahami } \\
\text { materi soal }\end{array}$ & 4 & 5 & 3 & 5 & 4 & 4 \\
\hline 6. & Tombol-tombol yang digunakan dalam program/media ini menarik & 5 & 3 & 3 & 4 & 4 & 3 \\
\hline & Rerata & \multicolumn{6}{|c|}{3,83} \\
\hline \multicolumn{8}{|c|}{ Pengoperasian Program } \\
\hline 7. & Petunjuk penggunaan program/media ini mudah dipahami & 4 & 5 & 5 & 4 & 5 & 5 \\
\hline 8. & Program/media ini mudah digunakan & 5 & 3 & 4 & 4 & 3 & 4 \\
\hline & Rerata & \multicolumn{6}{|c|}{4,25} \\
\hline \multicolumn{8}{|c|}{ Bahasa } \\
\hline 9. & Bahasa yang digunakan dalam program/media ini jelas & 5 & 4 & 4 & 3 & 4 & 5 \\
\hline 10. & Kata-kata yang digunakan dalam program/media ini mudah dipahami & 5 & 5 & 4 & 4 & 4 & 3 \\
\hline & Rerata & \multicolumn{6}{|c|}{4,17} \\
\hline \multicolumn{8}{|c|}{ Kemanfaatan } \\
\hline 11. & Program/media ini dapat meningkatkan semangat saya dalam belajar & 5 & 3 & 4 & 4 & 3 & 5 \\
\hline 12. & Program/media ini dapat melatih 140 ocus perhatian/konsentrasi saya & 5 & 3 & 4 & 3 & 4 & 4 \\
\hline 13. & Program/media ini mampu meningkatkan rasa percaya diri saya & 4 & 4 & 3 & 3 & 3 & 4 \\
\hline 14. & Saya mudah memahami materi menggunakan program/media ini & 5 & 3 & 4 & 4 & 5 & 4 \\
\hline 15. & Belajar menjadi kegiatan yang menyenangkan dengan menggunakan progam/media ini & 5 & 5 & 5 & 4 & 3 & 5 \\
\hline & Rerata & \multicolumn{6}{|c|}{4,00} \\
\hline
\end{tabular}

Berdasarkan Tabel 5, jika dinilai sacara keseluruhan maka rerata skor tanggapan menurut siswa dalam beta test adalah 4,06. Rerata tersebut terrmasuk dalam kriteria 'baik'. Berdasarkan hasil skor tanggapan siswa dalam beta test tersebut maka dapat dinyatakan bahwa paket latihan dan penilaian yang dikembangkan layak untuk digunakan dalam pembelajaran.

Selain memberikan skor tanggapan terhadap media, siswa juga mengisi lembar komentar/saran. Berdasarkan saran tersebut, dua komentar yang menjadi bahan pertimbangan untuk melakukan perbaikan yang disampaikan sebagai berikut. (1) Musik yang kurang semangat dan terlalu lemah yang disampaikan oleh 3 siswa, sementara itu 3 siswa yang lain menyatakan bahwa musik instrumental yang digunakan cukup membantu konsentrasi dan tidak mengganggu/bising. Untuk mengatasi hal tersebut maka solusinya adalah dengan menyediakan musik pada materi rujukan dengan suara yang lebih semangat. Dengan cara ini siswa yang menginginkan untuk belajar dengan musik yang agak keras dapat menghidupkan musiknya, sedangkan yang ingin mendengarkan musik instrumental juga dapat mendengarkan musik tersebut. (2) Pada simulasi pengukuran outside micrometer yang menggunakan animasi flash terkadang terdapat gambar pengukuran yang kurang tepat penunjukan skalanya. Meskipun demikian, simulator dengan flash tersebut memiliki keunggulan di mana visualisasinya sangat mendekati alat ukur outside micrometer yang asli. Selain itu, dengan suara yang muncul ketika rachet dipuar maksimal akan memberikan pemahaman kepada siswa, sama ketika mereka menggunakan outside micrometer yang sebenarnya. Penunjukkan skala yang kurang tepat hanya terjadi sesekali saja. Siswa sudah memahami dan mampu mengasumsikannya sehingga jika terjadi kesalahan dapat menyesuaikan dengan penunjukkan skala yang dimaksudkan. Oleh karena itu, simulasi tersebut tetap digunakan.

Pada tahap evaluasi sumatif, siswa menyampaikan skor dan tanggapan yang selengkapnya disampaikan dalam Tabel 6. 
Tabel 6. Skor tanggapan Siswa dalam Evaluasi Sumatif

\begin{tabular}{|c|c|c|c|c|c|c|c|c|}
\hline \multirow{2}{*}{ No. } & \multirow{2}{*}{ Kriteria Penilaian } & \multicolumn{5}{|c|}{ Frekuensi Skor } & \multirow{2}{*}{$\begin{array}{l}\text { Jumlah Skor } \\
\text { (frek x skor) }\end{array}$} & \multirow{2}{*}{$\begin{array}{l}\text { Rata-rata } \\
\text { Skor }\end{array}$} \\
\hline & & 5 & 4 & 3 & 2 & 1 & & \\
\hline \multicolumn{9}{|c|}{ Kefektifan Desain Layar (Kualitas tampilan) } \\
\hline 1 & $\begin{array}{l}\text { Tampilan program } / \text { media } \\
\text { menarik }\end{array}$ & 17 & 12 & 3 & 0 & 0 & 142 & 4,4375 \\
\hline 2 & $\begin{array}{l}\text { Teks/tulisan dalam } \\
\text { program/media ini mudah } \\
\text { dibaca }\end{array}$ & 9 & 14 & 8 & 1 & 0 & 127 & 3,96875 \\
\hline 3 & $\begin{array}{l}\text { Musik/suara yang digunakan } \\
\text { dapat mendukung suasana } \\
\text { belajar }\end{array}$ & 3 & 13 & 11 & 5 & 0 & 110 & 3,4375 \\
\hline 4 & $\begin{array}{l}\text { Gambar/animasi yang digunakan } \\
\text { dalam program/media ini } \\
\text { menarik }\end{array}$ & 16 & 11 & 4 & 0 & 1 & 137 & 4,28125 \\
\hline 5 & $\begin{array}{l}\text { Gambar/animasi yang digunakan } \\
\text { dalam program/media ini } \\
\text { memudahkan saya memahami } \\
\text { materi soal }\end{array}$ & 11 & 17 & 3 & 1 & 0 & 134 & 4,1875 \\
\hline 6 & $\begin{array}{l}\text { Tombol-tombol yang digunakan } \\
\text { dalam program/media ini } \\
\text { menarik }\end{array}$ & 5 & 11 & 16 & 0 & 0 & 117 & 3,65625 \\
\hline \multicolumn{8}{|c|}{ Rerata } & 3,994792 \\
\hline \multicolumn{9}{|c|}{ Pengoperasian Program } \\
\hline 7 & $\begin{array}{l}\text { Petunjuk penggunaan } \\
\text { program/media ini mudah } \\
\text { dipahami }\end{array}$ & 11 & 11 & 10 & 0 & 0 & 129 & 4,03125 \\
\hline 8 & $\begin{array}{l}\text { Program/media ini mudah } \\
\text { digunakan }\end{array}$ & 12 & 13 & 5 & 2 & 0 & 131 & 4,09375 \\
\hline \multicolumn{8}{|c|}{ Rerata } & 4,0625 \\
\hline \multicolumn{9}{|c|}{ Bahasa } \\
\hline 9 & $\begin{array}{l}\text { Bahasa yang digunakan dalam } \\
\text { program/media ini jelas }\end{array}$ & 7 & 17 & 8 & 0 & 0 & 127 & 3,96875 \\
\hline 10 & $\begin{array}{l}\text { Kata-kata yang digunakan dalam } \\
\text { program/media ini mudah } \\
\text { dipahami }\end{array}$ & 3 & 19 & 10 & 0 & 0 & 121 & 3,78125 \\
\hline \multicolumn{8}{|c|}{$\begin{array}{rr} & \text { Rerata } \\
\end{array}$} & 3,875 \\
\hline \multicolumn{9}{|c|}{ Kefektifan Desain Layar (Kualitas tampilan) } \\
\hline 11 & $\begin{array}{l}\text { Program/media ini dapat } \\
\text { meningkatkan semangat saya } \\
\text { dalam belajar }\end{array}$ & 15 & 10 & 6 & 1 & 0 & 135 & 4,21875 \\
\hline 12 & $\begin{array}{l}\text { Program/media ini dapat melatih } \\
\text { fokus perhatian/konsentrasi saya }\end{array}$ & 10 & 12 & 8 & 1 & 1 & 125 & 3,90625 \\
\hline 13 & $\begin{array}{l}\text { Program/media ini mampu } \\
\text { meningkatkan rasa percaya diri } \\
\text { saya }\end{array}$ & 8 & 10 & 12 & 2 & 0 & 120 & 3,75 \\
\hline 14 & $\begin{array}{l}\text { Saya mudah memahami materi } \\
\text { menggunakan program/media } \\
\text { ini }\end{array}$ & 9 & 15 & 7 & 1 & 0 & 128 & 4 \\
\hline 15 & $\begin{array}{l}\text { Belajar menjadi kegiatan yang } \\
\text { menyenangkan dengan } \\
\text { menggunakan progam/media ini }\end{array}$ & 21 & 7 & 4 & 0 & 0 & 145 & 4,53125 \\
\hline \multicolumn{8}{|c|}{ Rerata } & 4,08125 \\
\hline
\end{tabular}

Secara keseluruhan, untuk menilai kelayakan paket latihan dan penilaian ini, maka ditentukan berdasarkan skor validasi oleh ahli materi, ahli evaluasi, ahli media, dan tanggapan siswa. Jika dinilai secara keseluruhan, skor rata-rata yang didapatkan adalah 4,29. Berdasarkan tabel kriteria, maka skor kelayakan tersebut termasuk dalam kategori "sangat baik". Kesimpulan akhir yang didapatkan adalah bahwa paket latihan dan penilaian yang dikembangkan layak digunakan dalam pembelajaran. Hasil penilaian kelayakan produk berdasarkan skor validasi oleh ahli materi, ahli evaluasi, ahli media, dan tanggapan siswa tersebut dapat divisualisasikan dalam Gambar 3. 


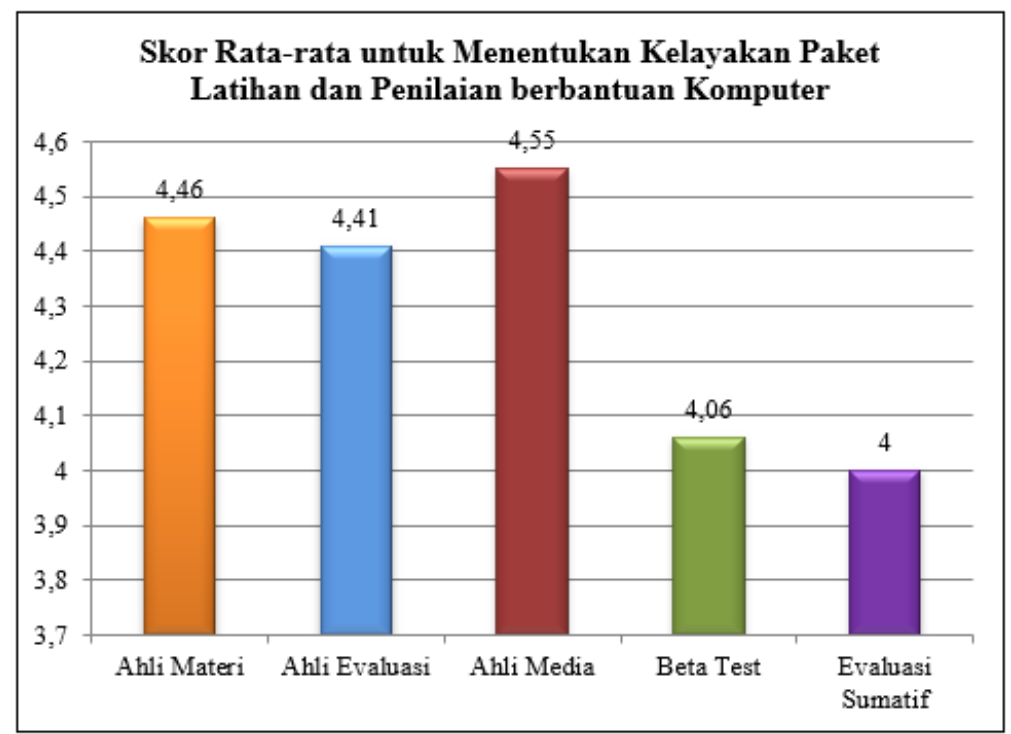

Gambar 3. Diagram Batang Skor Rata-rata untuk Menentukan Kelayakan Paket Latihan dan Penilaian

Setelah terbukti paket latihan dan penilaian yang dikembangkan layak dipakai, maka tahap terakhir adalah diseminasi. Produk yang dihasilkan dikemas dalam bentuk $C D$ pembelajaran yang telah dilengkapi dengan program auto-run atau auto-play. Produk tersebut kemudian disampaikan kepada pengguna dan profesional yaitu guru metrologi melalui forum pertemuan. Langkah-langkah pengembangan paket latihan dan penilaian berbantuan komputer untuk pembelajaran alat ukur mekanik presisi ini secara ringkas disampaikan dalam Tabel 7.

Tabel 7. Langkah-langkah Pengembangan Paket Latihan dan Penilaian Berbantuan Komputer untuk Pembelajaran Alat Ukur Mekanik Presisi

\begin{tabular}{lll}
\hline No. & \multicolumn{2}{c}{ Langkah-langkah Pengembangan Paket Latihan dan Penilaian Berbantuan Komputer } \\
\hline 1. & Studi Pendahuluan & $\begin{array}{l}\text { Studi pustaka, Survei lapangan, Identifikasi Permasalahan } \\
\text { Pembelajaran, Identifikasi Tujuan Pembuatan Media, Analisis } \\
\text { kebutuhan, Perencanaan (perumusan) desain produk }\end{array}$ \\
& & $\begin{array}{l}\text { Pembuatan Flowchart View, Pembuatan Storyboard, Pengumpulan } \\
\text { Bahan, Perakitan (assembly), Tes Secara Modular, Produk Awal }\end{array}$ \\
\hline 2. & Produksi & Uji Kelayakan oleh Ahli (alpha test), Uji Coba Terbatas ( beta test), \\
& & Analisis dan Revisi, Evaluasi Sumatif, Analisis dan Revisi, Produk \\
& Akhir \\
\hline 3. & Evaluasi & Menyampaikan produk hasil pengembangan kepada pengguna dan \\
& & profesional yaitu guru metrologi melalui forum pertemuan. \\
\hline 4. & Diseminasi &
\end{tabular}

Langkah-lengkah pengembangan paket latihan dan penilaian tersebut terbukti mampu menghasilkan produk multimedia yang layak digunakan dalam pembelajaran. Karena produk yang dikembangkan ini terdapat paket penilaian, maka soal-soal untuk pretest dan posttest diambilkan dari soal yang telah tervalidasi dan digunakan dalam penelitian kolaborasi dosen-mahasiswa oleh Wagiran (2010).

\section{SIMPULAN}

Bersasarkan hasil penelitian dan pembahasan, dapat ditarik kesimpulan sebagai berikut. (1) Pengembangan paket latihan dan penilaian berbantuan komputer untuk pembelajaran alat ukur mekanik presisi dilakukan melalui empat langkah utama yaitu: studi pendahuluan, produksi, evaluasi produk, dan diseminasi.(2) Paket latihan dan penilaian 
berbantuan komputer untuk pembelajaran alat ukur mekanik presisi layak digunakan untuk pembelajaran. Jika dinilai secara keseluruhan berdasarkan skor validasi oleh ahli materi, ahli evaluasi, ahli media, dan tanggapan siswa, maka skor rata-rata yang didapatkan adalah 4,29 sehingga termasuk kategori sangat baik.

\section{DAFTAR RUJUKAN}

Yazid, A. (2009). Pengembangan Media Pembelajaran Kimia Berbantuan Komputer (MPKBK) untuk SMA/MA. Tesis tidak diterbitkan. PPs-UNY.

Suartama, I.K. (2010). Pengembangan Multimedia untuk Meningkatkan Kualitas Pembelajaran pada Mata Kuliah Media Pembelajaran. Jurnal Pendidikan dan Pengajaran, Vol 43, Nomor 3, Oktober 2010 (hlm. 253262).
Sutikanti. (2008). Pengembangan Bahan Pembelajaran Berbantuan Komputer Untuk Memfasilitasi Active Learning Dalam Mata Kuliah Landasan Kependidikan. Tesis tidak diterbitkan. PPs-UNY.

Wagiran. (2008). "Pengembangan Media Pembelajaran Berbantuan Komputer dalam mendukung Perkuliahan Metrologi. Jurnal Kependidikan, Vol 38 No. 2, November 2008 (hlm. 225242).

Wagiran. (2010). "Pengembangan Media Pembelajaran Berbantuan Komputer untuk Meningkatkan Kualitas Perkuliahan Metrologi Industri”. Laporan Penelitian. Fakultas Teknik UNY. 